\title{
Capability of U-Pb dating of zircons from Quaternary tephra: Jemez Mountains, NM, and La Sal Mountains, UT, USA
}

\author{
Jana Krautz ${ }^{1}$, Mandy Hofmann², Andreas Gärtner ${ }^{2}$, Ulf Linnemann², and Arno Kleber ${ }^{1}$ \\ ${ }^{1}$ Institute of Geography, Technische Universität Dresden, Helmholtzstr. 10, 01690 Dresden, Germany \\ ${ }^{2}$ Senckenberg Naturhistorische Sammlungen Dresden, Museum für Mineralogie und Geologie, Sektion Geochronologie, \\ GeoPlasma Lab, Königsbrücker Landstraße 159, 01109 Dresden, Germany
}

Correspondence: Jana Krautz (jana.krautz@tu-dresden.de)

Relevant dates: $\quad$ Published: 31 January 2018

How to cite:

Krautz, J., Hofmann, M., Gärtner, A., Linnemann, U., and Kleber, A.: Capability of U-Pb dating of zircons from Quaternary tephra: Jemez Mountains, NM, and La Sal Mountains, UT, USA, E\&G Quaternary Sci. J., 67, 7-16, https://doi.org/10.5194/egqsj-67-7-2018, 2018.

Abstract:

Two Quaternary tephras derived from the Jemez Mountains, New Mexico - the Guaje and Tsankawi tephras - are difficult to distinguish due to their similar glass-shard chemical composition. Differences in bulk chemical composition are small as well. Here we examine the feasibility to assign an age to a distal tephra layer in the La Sal Mountains, Utah, by U-Pb dating of zircons and to correlate it with one of the two Jemez eruptions. We also dated original Jemez tephras for comparison. Even though the tephras are very young, we obtained reasonable age determinations using the youngest cluster of zircon grains overlapping in age at $2 \sigma$. Thereafter, the Guaje tephra is $1.513 \pm 0.021$ Myr old. The La Sal Mountains tephra is correlated with the Tsankawi tephra. Three samples yielded a common age range of 1.31-1.40 Myr. All ages are in slight disagreement with published age determinations obtained by ${ }^{40} \mathrm{Ar} /{ }^{39} \mathrm{Ar}$ dating. These findings indicate that distal Jemez tephras can be distinguished by $\mathrm{U}-\mathrm{Pb}$ dating. Furthermore, we encourage giving this method a try for age assignments even of Quaternary volcanic material.

Kurzfassung: $\quad$ Zwei quartäre Tephren aus den Jemez Mountains, New Mexico, - Guaje- und Tsankawi-Tephra sind durch die ähnliche chemische Zusammensetzung ihrer Gläser nur schwer zu unterscheiden. Dies gilt auch, bis auf geringfügige Unterschiede, für die Totalanalyse. Wir haben die Möglichkeit untersucht, das Alter einer distalen Tephralage in den La Sal Mountains, Utah, zu bestimmen und einer der Tephren aus den Jemez Mountains zuzuordnen. Zur Vergleichbarkeit haben wir auch die Zirkone der Tephren aus den Jemez Mountains U-Pb datiert. Obwohl die Tephren alle sehr jung sind, haben wir reliable Alter durch das Cluster der jüngsten, im $2 \sigma$ Fehler überlappenden Zirkone erhalten. Demzufolge ist die Guaje-Tephra 1.513 $\pm 0.021 \mathrm{Myr}$ alt. Die Tephra aus den La Sal Mountains wurde mit der Tsankawi-Tephra korreliert: Drei Proben aus den Jemez Mountains $(1 \times)$ und den La Sal Mountains $(2 \times)$ ergaben eine Altersspanne von 1.31-1.40 Myr. Alle Alter weichen etwas von bereits publizierten ${ }^{40} \mathrm{Ar} /{ }^{39} \mathrm{Ar} \mathrm{ab}$. Die Ergebnisse deuten darauf hin, dass die distalen Jemez-Tephren durch $\mathrm{U}-\mathrm{Pb}$ Datierung unterschieden werden können. Wir wollen dazu ermutigen, diese Methode der Altersbestimmung auch für quartäres vulkanisches Material in Erwägung zu ziehen. 
Tephra is eruptive rock material deposited as airborne fallout often quite distant from its source volcano. Because of its chemical composition - usually obtained from glass shards - it often may be related to a particular volcanic eruption (Westgate et al., 1994). Therefore, tephrochronology has become an established method, using tephra intercalated between other deposits as a stratigraphic marker bed, provided the original eruption is well dated (Lowe, 2011).

There are a lot of reliable methods for dating Quaternary tephra (Dickinson and Gehrels, 2009). Most commonly the ${ }^{40} \mathrm{Ar} /{ }^{39} \mathrm{Ar}$ method is applied using K-rich minerals (Lowe, 2011). This utilizes the fact that embedded argon completely leaves the mineral lattice by disturbances such as a volcanic eruption. After this the enrichment by radioactive decay of $\mathrm{K}$ re-starts, and thenceforward the accrued isotopes may be measured. So ages can be calculated via the half-life of the isotopes (Worsley, 1998).

A distal tephra layer discovered in the La Sal Mountains, Utah, was linked to the volcanic province of the Jemez Mountains, New Mexico, based on glass-shard chemistry. However, correlation with a particular eruption remained ambiguous (Kleber, 2013), because two tephras derived from there have closely similar chemical compositions (Slate et al., 2007) - one of the major threads of tephrochronology (Lowe, 2011). Zimmerer et al. (2016) state that both tephras are difficult to date by $\mathrm{Ar}-\mathrm{Ar}$ dating, asking for elaborate sample preparation and calculation of the results. Though still not done very often on such young zircons (Lee, 2012), there have been a few successful applications of U-Pb dating of zircons to young material in recent years (e.g., Ito et al., 2016; Sakata et al., 2017). Zircons have the advantage of being outstandingly chemically and physically robust. They are unsusceptible to alteration and weathering even under extreme conditions (Wilson et al., 2008). Thus, we tried dating the tephra layer using zircon dating.

Here we demonstrate reasonable age determinations of zircons from the La Sal Mountains tephra layer and of the two suspect tephras in the Jemez Mountains. Through this, the Jemez tephra layers may be discriminated with high certainty. Furthermore, we encourage giving the U-Pb method - which is available in a variety of labs worldwide - a try for dating volcanic material of undisclosed age even if the assumed age is as young as $1 \mathrm{Myr}$, after having tested the total uranium contents.

\section{Geological setting}

\subsection{Jemez Mountains, New Mexico}

The Jemez Mountains (Fig. 1) are calderas of various volcanic eruptions, among which the Valles, Antonio, and Toledo calderas are still recognizable as concentric moun- tain ranges. Their eruptive products, mainly basalt-andesitedacite-rhyolite associations, range from about $15 \mathrm{Myr}$ (midMiocene) to <2 Myr (Pleistocene) (Kues et al., 2007). The Neogene and Quaternary formations are divided into three groups, named after Indian nations, from oldest to youngest: the Keres, the Polvadera, and the Tewa group (Bailey et al., 1969). We took our samples from the Tewa group. This comprises the Bandelier Tuff, which is mainly the result of two large ignimbrite- and caldera-forming eruptions. The lower Otowi (including the Guaje tephra) and the upper Tshirege (including the Tsankawi tephra) sequences were deposited approximately 1.6 and 1.2 Ma, respectively (Self et al., 1996; Slate et al., 2007). Today large parts of these ignimbrite and tephra sequences belong to the Bandelier National Monument.

The Jemez Mountains are known to be the source area of the La Sal Mountains tephra layer. We took samples approximately $8 \mathrm{~km}$ southeast of Los Alamos, New Mexico, from a slope along New Mexico State Road 502 (Guaje and Tsankawi tephras, located at $35^{\circ} 52^{\prime} 05^{\prime \prime} \mathrm{N}, 106^{\circ} 11^{\prime} 59^{\prime \prime} \mathrm{W}$ and at $35^{\circ} 52^{\prime} 05^{\prime \prime} \mathrm{N}, 106^{\circ} 12^{\prime} 00^{\prime \prime} \mathrm{W}$, respectively). The site is depicted in Goff (2009) and in Fig. 2a.

\subsection{La Sal Mountains, Utah}

The chain of the La Sal Mountains lies at the eastern border of Utah (Fig. 1). Like the Jemez Mountains, it is part of the Colorado Plateau Province and together with Mount Peale (3877 $\mathrm{m}$ a.s.1.) is the highest peak of the plateau (Henning, 1975; Grahame and Sisk, 2002). The La Sal Mountains are remnants of laccoliths and mainly consist of granitoid rocks (Henning, 1975; Ross, 2006). The Precambrian basement is unconformably overlain by Paleozoic and Mesozoic sedimentary rocks, which were intruded by monzonite and diorite porphyry during the Paleogene $(\mathrm{K}-\mathrm{Ar}$ ages are 25-28 Myr; Ross, 2006). The laccolithic structures preserve Mesozoic rocks at the mountain flanks, mainly clays and sandstones (Richmond, 1962; Henning, 1975). Within the adjacent Paradox Basin, the Mesozoic rock sequence is underlain by marine sediments, which include limestone, dolomite, slate, and a several-hundreds-of-meters-thick diapiric layer of salt and gypsum (Henning, 1975).

A distal tephra layer was found in the northwestern La Sal Mountains, Utah, USA (located $38^{\circ} 34^{\prime} 33^{\prime \prime} \mathrm{N}$, $109^{\circ} 17^{\prime} 32^{\prime \prime} \mathrm{W}$ ), approximately $20 \mathrm{~km}$ linear distance from Moab, Utah, at $2130 \mathrm{~m}$ a.s.l., on a $22^{\circ}$ steep slope, exposed by a road cut of the Manti-La Sal Circuit (Kleber, 2013 and Fig. 2b). The tephra was identified by the US Geological Survey, Tephrochronology Laboratory, Menlo Park, CA, via the chemical composition of its glass shards. It was correlated with either the approximately 1.25 Myr old (Phillips et al., 2007) Tsankawi tephra or - because of the Fe contents somewhat more likely - the approximately $1.65 \mathrm{Myr}$ old (Spell 


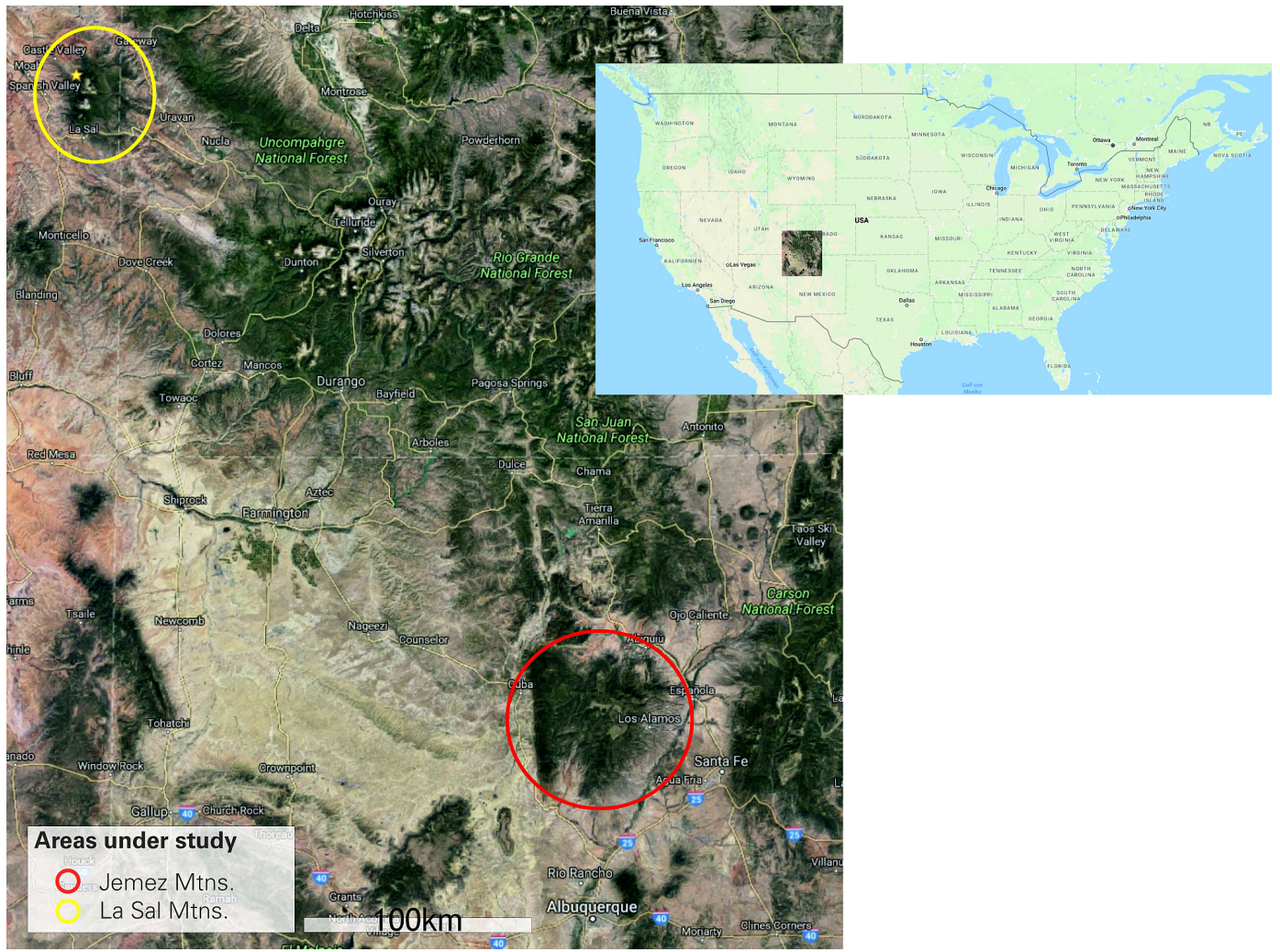

Figure 1. Areas under study. Source of maps: Google Maps 2016 (http://maps.google.com).

and Harrison, 1993) Guaje tephra, both derived from the Jemez Mountains, New Mexico (Kleber, 2013).

\section{Methods}

We took two samples from the deposition area in the La Sal Mountains, UT, USA, and one from each original tephra layer, derived from the Toledo Caldera (Guaje tephra) and from the Valles Caldera (Tsankawi tephra). The latter two - taken from well-known tephra locations - were mainly measured to disclose whether the results of the U-Pb determinations are consistent with the aforementioned earlier ${ }^{40} \mathrm{Ar} /{ }^{39} \mathrm{Ar}$ datings and may, thus, yield reliable ages of distal tephra layers.

We performed sample preparation for cathodoluminescence (CL) images, LA-ICP-MS (laser ablation with inductively coupled plasma mass spectrometry) $\mathrm{U}-\mathrm{Pb}$ analyses, and age calculations at the Geochronology Department of Senckenberg Naturhistorische Sammlungen Dresden, Germany. Circa $1 \mathrm{~kg}$ of material was collected for each sample. After crushing in a jaw crusher, the samples were sieved for the fraction 36 to $400 \mu \mathrm{m}$. Density separation of this fraction was accomplished with LST (solution of lithium heteropolytungstates in water). We used a Frantz isodynamic separator for the magnetic separation of the extracted heavy minerals. Single zircon grains of all grain sizes, colors, and mor- phological types were randomly picked under a binocular microscope and subsequently analyzed regarding their morphology based on backscatter electron (BSE) images of the unmounted zircon grain surfaces using a Zeiss EVO50SEM at $20 \mathrm{kV}$ and a spot size of $300 \mathrm{~nm}$. Then the grains were mounted in resin blocks and polished to approximately half their thickness, in order to expose their internal structure. We obtained CL images using a Zeiss EVO50SEM coupled to a $\mathrm{CL}$ detector system at $20 \mathrm{kV}$ and a spot size of $500 \mathrm{~nm}$. Zircons were analyzed for $\mathrm{U}, \mathrm{Th}$, and $\mathrm{Pb}$ isotopes by LA-ICPMS, utilizing a Thermo Scientific ELEMENT 2 XR sector field ICP-MS coupled to a New Wave UP-193 excimer laser system with laser spot sizes of 20 to $35 \mu \mathrm{m}$. Fifteen seconds of background acquisition was followed by $25 \mathrm{~s}$ of data acquisition during each analysis. The signal was tuned for a maximum sensitivity for $\mathrm{Pb}$ and $\mathrm{U}$, whereas oxide production $\left({ }^{235} \mathrm{UO}\right.$ vs. $\left.{ }^{238} \mathrm{U}\right)$ was kept well below $1 \%$. Raw data were corrected for background signal, common $\mathrm{Pb}$, laserinduced elemental fractionation, instrumental mass discrimination, and time- and depth-dependent elemental fractionation of $\mathrm{Pb} / \mathrm{Th}$ and $\mathrm{Pb} / \mathrm{U}$ using an Excel ${ }^{\circledR}$ macro developed by Axel Gerdes (Geosciences Inst., Goethe University Frankfurt, Germany). Reported uncertainties were propagated by quadratic addition of the external reproducibility obtained from the standard zircon GJ-1 $(\sim 0.6$ and $0.5-$ $1 \%$ for ${ }^{207} \mathrm{~Pb} /{ }^{206} \mathrm{~Pb}$ and ${ }^{206} \mathrm{~Pb} /{ }^{238} \mathrm{U}$, respectively) dur- 

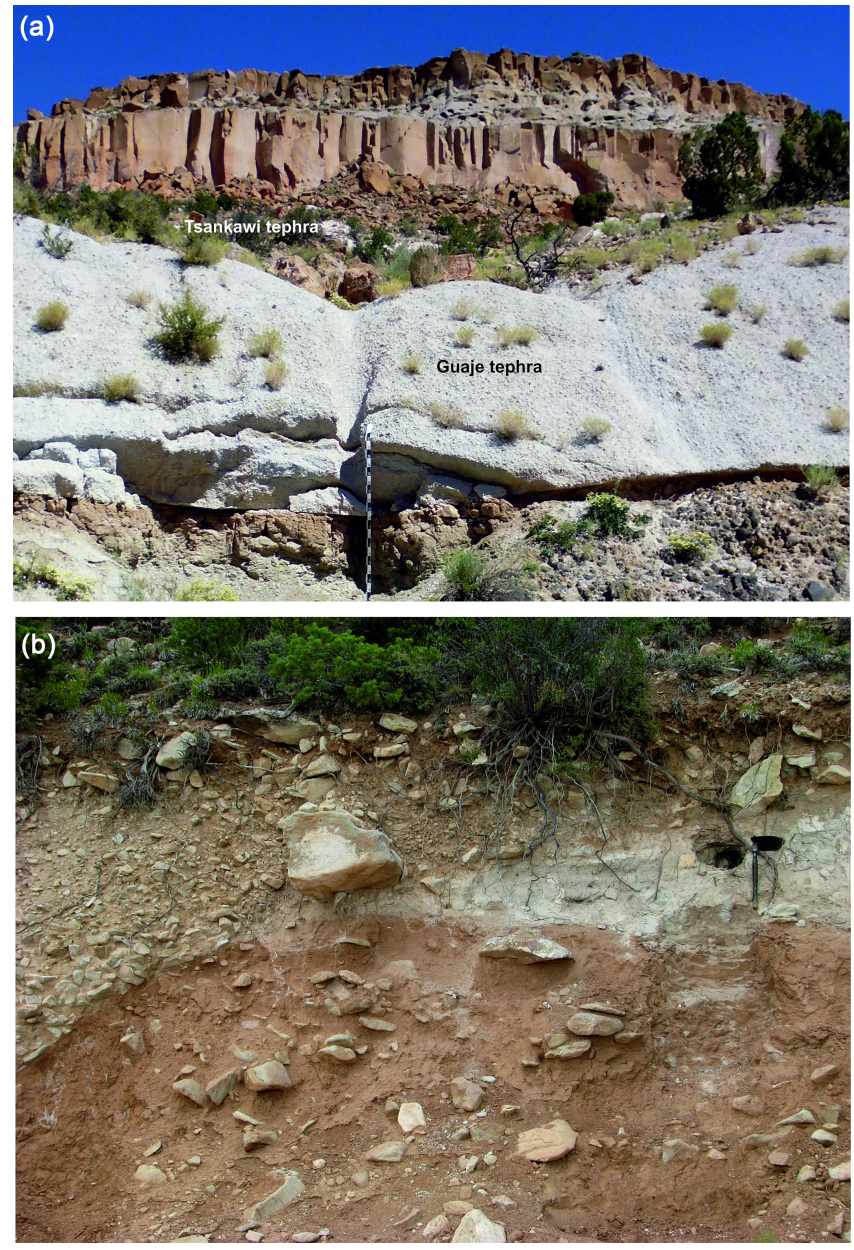

Figure 2. (a) Sampling sites of tephras in the Jemez Mountains. All visible rocks are volcanic in origin. Photo: Jana Krautz (22 August 2014). (b) Sampling site in the La Sal Mountains. The whitish tephra intercalates between periglacial cover beds and is to the left of the picture cut by a gully fill. Photo: Arno Kleber (27 July 2009). The sampling spot visible in the La Sal Mountains tephra was for radiofluorescence dating, not for the present dating.

ing individual analytical sessions and the within-run precision of each analysis. Concordia diagrams ( $2 \sigma$ error ellipses) and concordia ages ( $95 \%$ confidence level) were created using Isoplot/Ex 2.49 (Ludwig, 2001). ${ }^{207} \mathrm{~Pb} /{ }^{206} \mathrm{~Pb}$ ages were used for concordant analyses of zircons above $1.0 \mathrm{Ga}$, and ${ }^{206} \mathrm{~Pb} /{ }^{238} \mathrm{U}$ ages for younger ones. For ages younger than $10 \mathrm{Myr}$, we corrected for ${ }^{230} \mathrm{Th}$ disequilibrium using the formula of Simon et al. (2008).

Geochemical analyses of bulk samples were performed at Activation Laboratories Ltd. (Ancaster, Ontario, Canada) using their standard protocols RX4 for sample preparation and 4LITHO-Quant Major Elements Fusion ICP (WRA)/Trace Elements Fusion ICP-MS (WRA4B2) for the analyses as described on their website (ActLabs, 2014). The samples from the La Sal Mountains were contaminated with pedogenic 
(a)

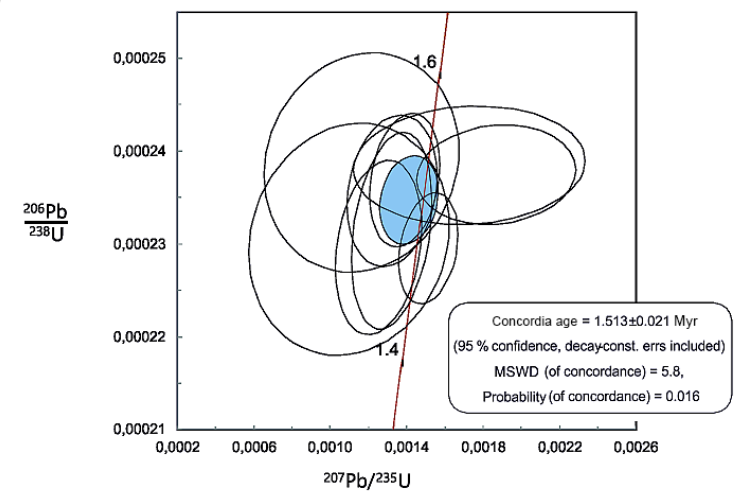

(b)

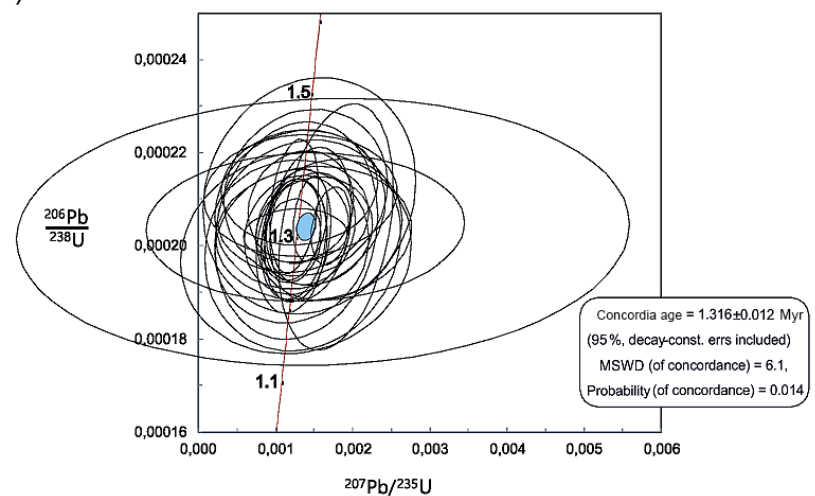

(c)

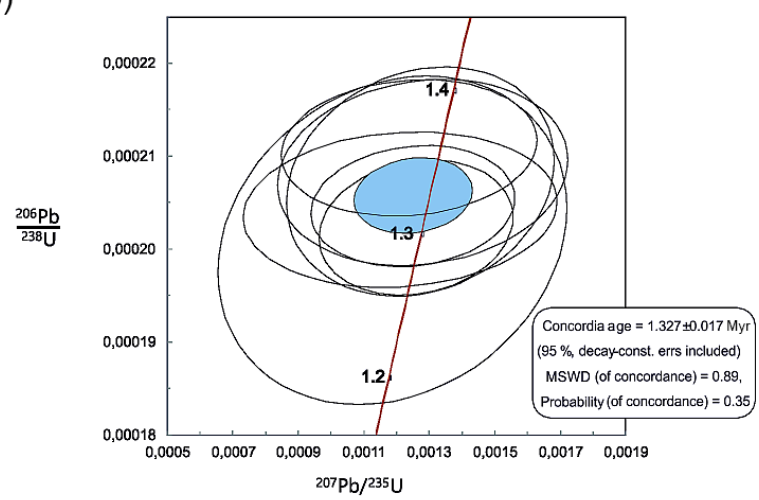

(d)

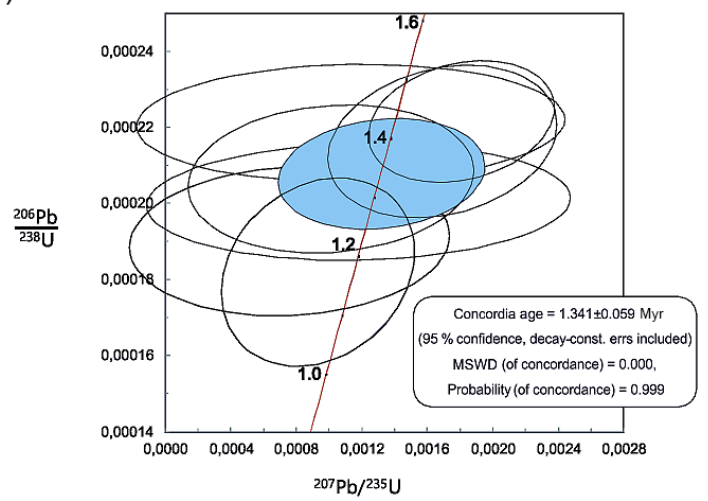

Data error ellipses are $2 \sigma$

Figure 3. Ages of tephra layers as derived from the youngest cluster of grain ages overlapping at the $2 \sigma$ level. (a) Guaje tephra, (b) Tsankawi tephra, (c) La Sal Mountains tephra sampled in 2013, (d) same but sampled in 2014.

carbonates, whereas the samples from the Jemez Mountains were not, or at least not to the same degree. Therefore, the major elements (and the total percentages) were re-calculated on a carbonate-free basis, i.e., without considering $\mathrm{MgO}$, $\mathrm{CaO}$, and loss on ignition (LOI), though the original values of these three measurements are given so that one could re-assemble all original quantities. In addition to the aforementioned samples, we analyzed a confirmed Guaje tephra sample provided by David B. Dethier (Slate et al., 2007).

Microprobe analyses were conducted aided by a CAMECA SX51 electron microprobe with five wavelengthdispersive spectrometers at the Earth Sciences Institute at Heidelberg University. The standard operating conditions were $15 \mathrm{kV}$ accelerating voltage, $20 \mathrm{nA}$ beam current, and a beam diameter of ca. $20 \mu \mathrm{m}$. Counting times during analyses were $10 \mathrm{~s}$ for $\mathrm{Na}$ and $\mathrm{K} ; 20 \mathrm{~s}$ for $\mathrm{Fe}$; $30 \mathrm{~s}$ for $\mathrm{Mn}$ and $\mathrm{P}$; and $50 \mathrm{~s}$ for $\mathrm{Si}, \mathrm{Ti}, \mathrm{Al}, \mathrm{Mg}$, and $\mathrm{Ca}$. Detection limits were $0.02 \mathrm{wt} \%$ for $\mathrm{Si}, \mathrm{Al}$, and $\mathrm{Ca}, 0.001 \mathrm{wt} \%$ for $\mathrm{Ti}$ and $\mathrm{Mn}$, $0.08 \mathrm{wt} \%$ for $\mathrm{Fe}$, and $0.09 \mathrm{wt} \%$ for $\mathrm{K}$ and $\mathrm{Na}$. Calibration was performed using natural and synthetic oxide and silicate standards. Values given are weight-percent oxide, re-calculated to be $100 \%$ fluid-free.

\section{Results and discussion}

The microprobe analyses of glass shards corroborate the great similarity of the Guaje and the La Sal Mountains tephras (Table 1; cf. Supplement for raw data). Even the differences in Fe contents, typically acknowledged as the only clue to distinguish Guaje from Tsankawi tephras (Andrei M. Sarna-Wojcicki, personal communication, 1990), are within the standard deviations of the analyses.

Table 2 shows that the major and especially the trace element concentrations from bulk samples of the La Sal Mountains tephra are very close to the Tsankawi tephra from the Jemez Mountains but somewhat dissimilar to the Guaje tephra sample as well as to the Guaje sample DN-97-117 submitted by David B. Dethier. This holds especially true for the elements shaded in yellow in Table 2, with the most remarkable being $\mathrm{Cr}, \mathrm{Rb}, \mathrm{Nb}$, and $\mathrm{Th}$. The differences in the $\mathrm{Sr}$ and Ba contents between the La Sal Mountains and Jemez Mountains samples may be explained by eolian contamination, as both elements are frequent components of eolian deposits (Jones, 1986). Similar differences in Tl contents may be due to different durations of sample materials being ex- 


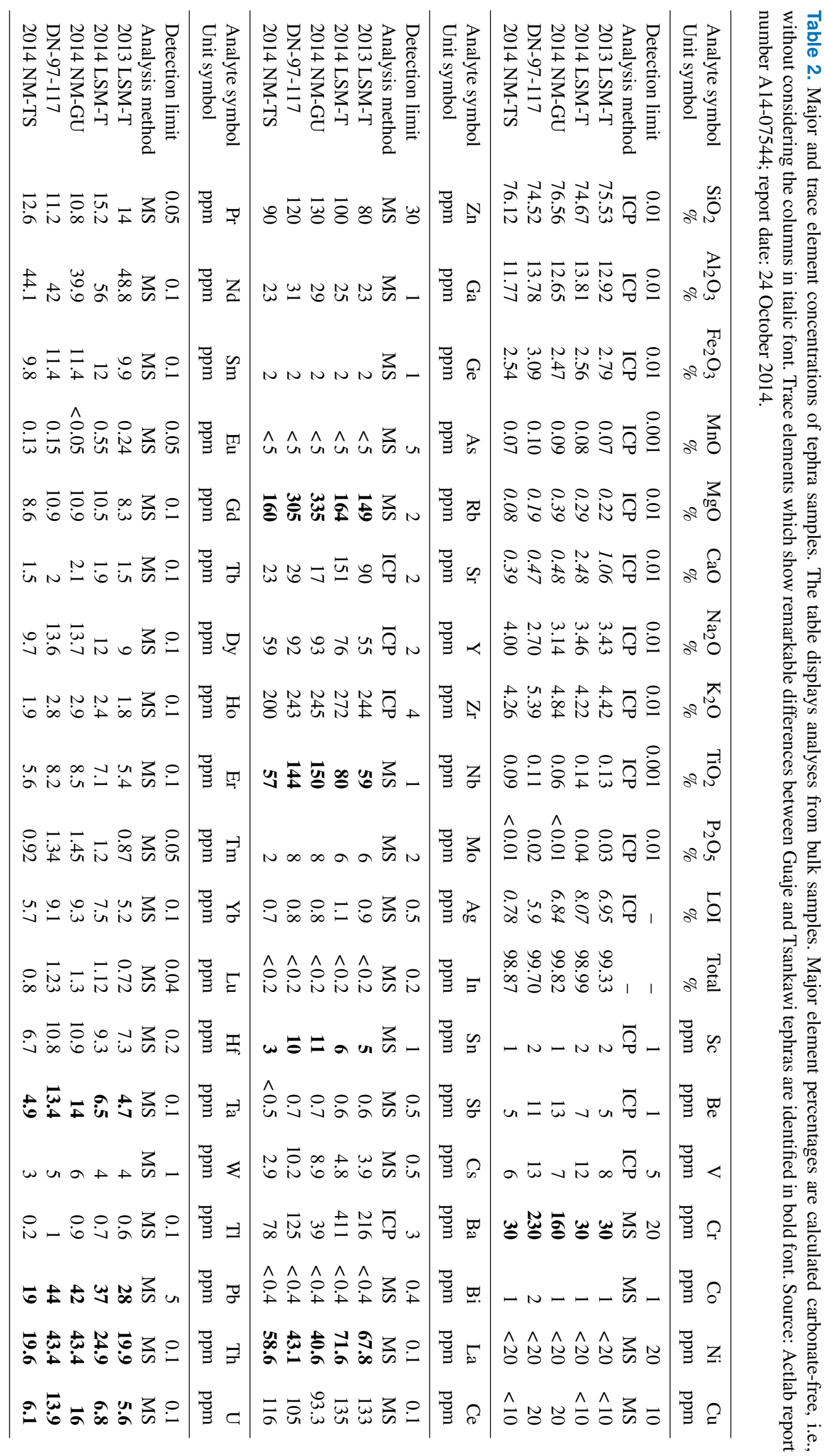


(a)

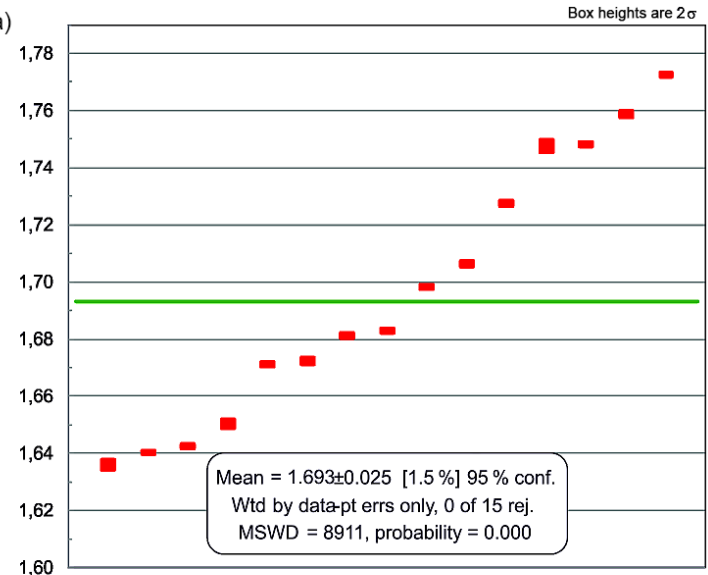

(b)

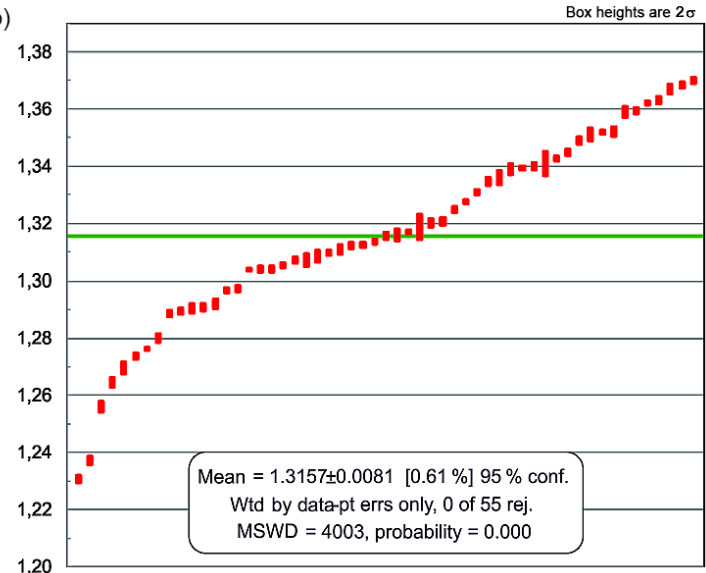

(c)

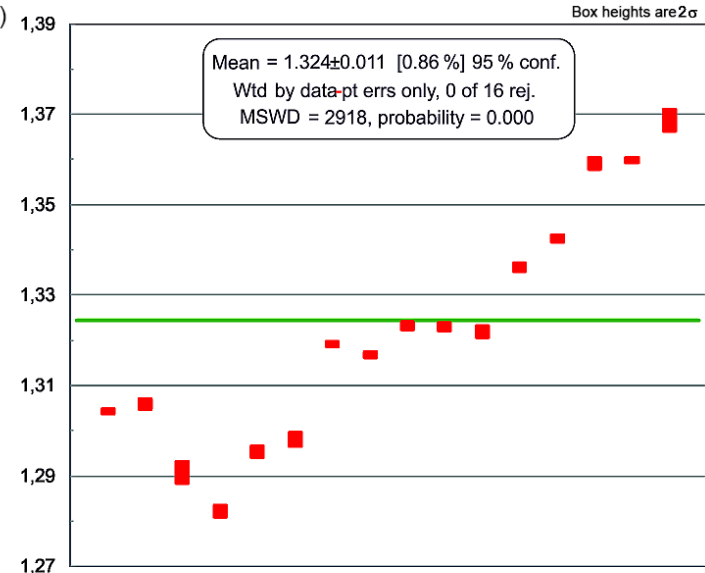

(d)

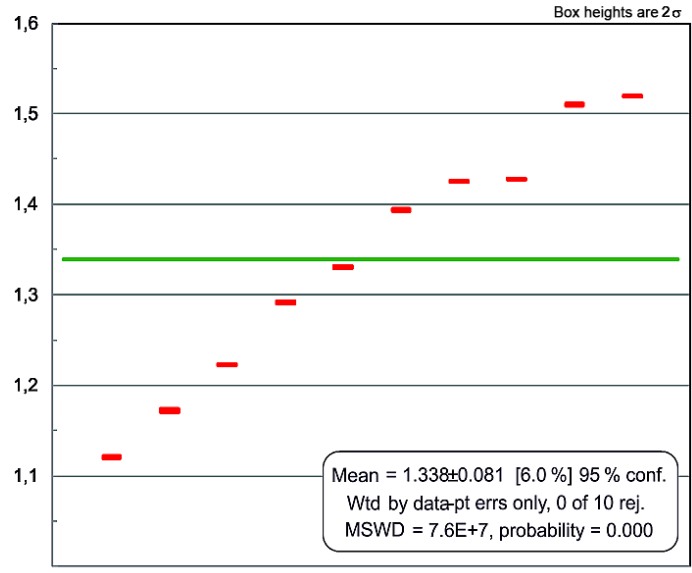

Figure 4. Weighted average ages of tephra layers to compare with the age displays. (a) Guaje tephra, (b) Tsankawi tephra, (c) La Sal Mountains tephra sampled in 2013, (d) same but sampled in 2014.

posed to oxidation. These findings render the La Sal Mountains tephra correlative to the Tsankawi rather than the Guaje tephra.

In all samples, primary uranium contents in zircons were sufficiently high to allow reliable age determinations. Given the apparently young ages of the tephras, ${ }^{207} \mathrm{~Pb}$ could not be accumulated in quantities remarkably above the detection limit of the instrument due to the extremely long halflife of ${ }^{235} \mathrm{U}$ and/or insufficiently high $U$ contents to produce enough $\mathrm{Pb}$ in such short intervals of time (compare young grains in the Supplement). Thus, we could use only the ${ }^{206} \mathrm{~Pb} /{ }^{238} \mathrm{U}$ for age estimations (cf. Gehrels, 2014). Therefore, ${ }^{207} \mathrm{~Pb} /{ }^{235} \mathrm{U}$ and ${ }^{207} \mathrm{~Pb} /{ }^{206} \mathrm{~Pb}$ ratios for crossvalidation are not available; the degree of concordance cannot be calculated for these young zircon grains, and those data are left blank (Supplement). Accordingly, the ages we report are regarded as model ages.

To establish the age of each tephra sample, we used the youngest cluster of zircon-derived $\mathrm{U}-\mathrm{Pb}$ ages overlapping at $2 \sigma$. The mean age of the youngest cluster of grain ages that overlap in age at $2 \sigma$ is regarded as the most conserva- tive measure of age (Dickinson and Gehrels, 2009). These clusters may be seen as groups of analyses resulting in ages close together, thereby validating each other even without a reliable $\mathrm{Pb}-\mathrm{Pb}$ age. Grains with younger ${ }^{238} \mathrm{U} /{ }^{206} \mathrm{~Pb}$ ages than the ones used for the calculation of the concordia ages (cf. Supplement) are not part of such a cluster in the concordia plot and, thus, cannot be cross-validated. Accordingly, they were not considered sufficiently reliable.

The grains used for age determination are accentuated in tables in the Supplement. The clusters are sufficiently large for the ages to be constrained to small confidence intervals $(2 \sigma)$; see also Figs. 3 and 4: we assigned an age of $1.513 \pm 0.021 \mathrm{Myr}$ to the Guaje tephra from the Jemez Mountains, which is somewhat younger than the published Ar-Ar-derived ages of $1.651 \pm 0.011 \mathrm{Myr}$ (Zimmerer et al., 2016) or $1.613 \pm 0.011 \mathrm{Myr}$ (Izett and Obradovich, 1994). The other three samples yielded ages incompatible with the Guaje tephra: the Tsankawi tephra from the Jemez Mountains was determined to be as old as $1.316 \pm 0.012 \mathrm{Myr}$. The two samples from the La Sal Mountains yielded ages of $1.327 \pm 0.017 \mathrm{Myr}$ (sample from the year 2013) and 

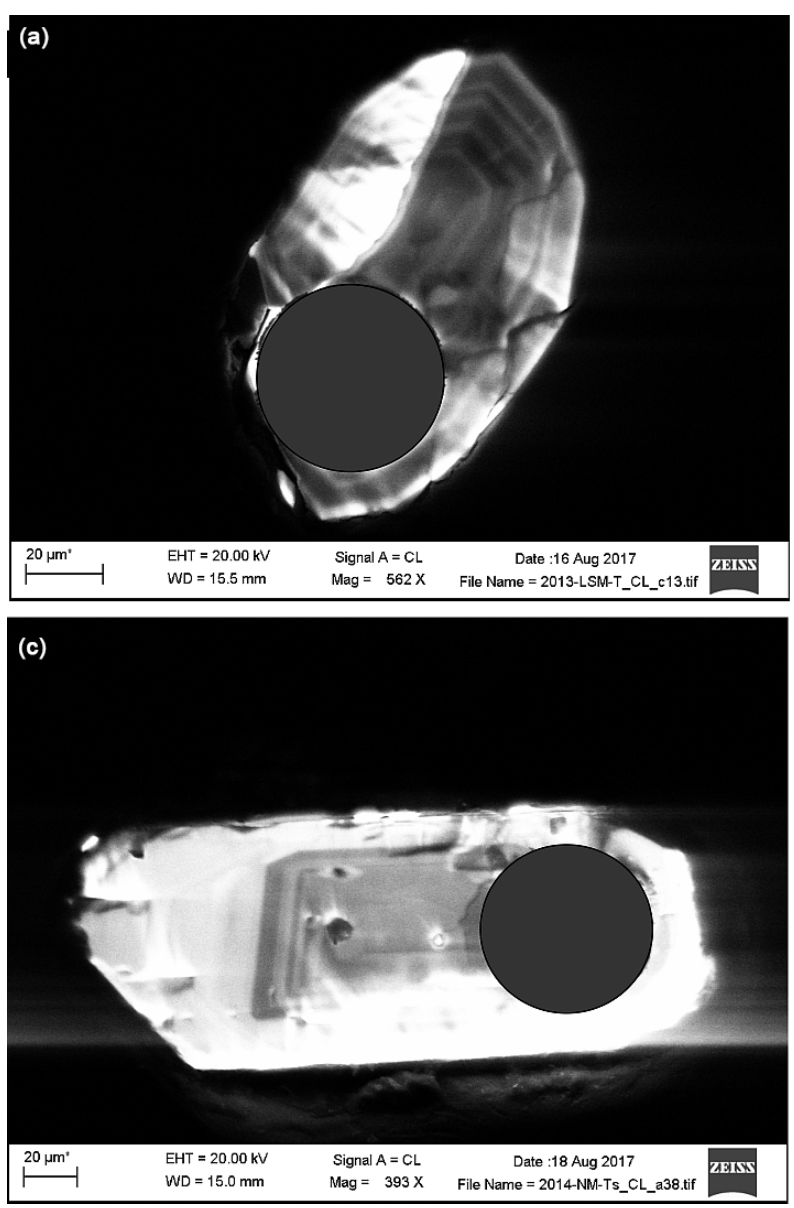
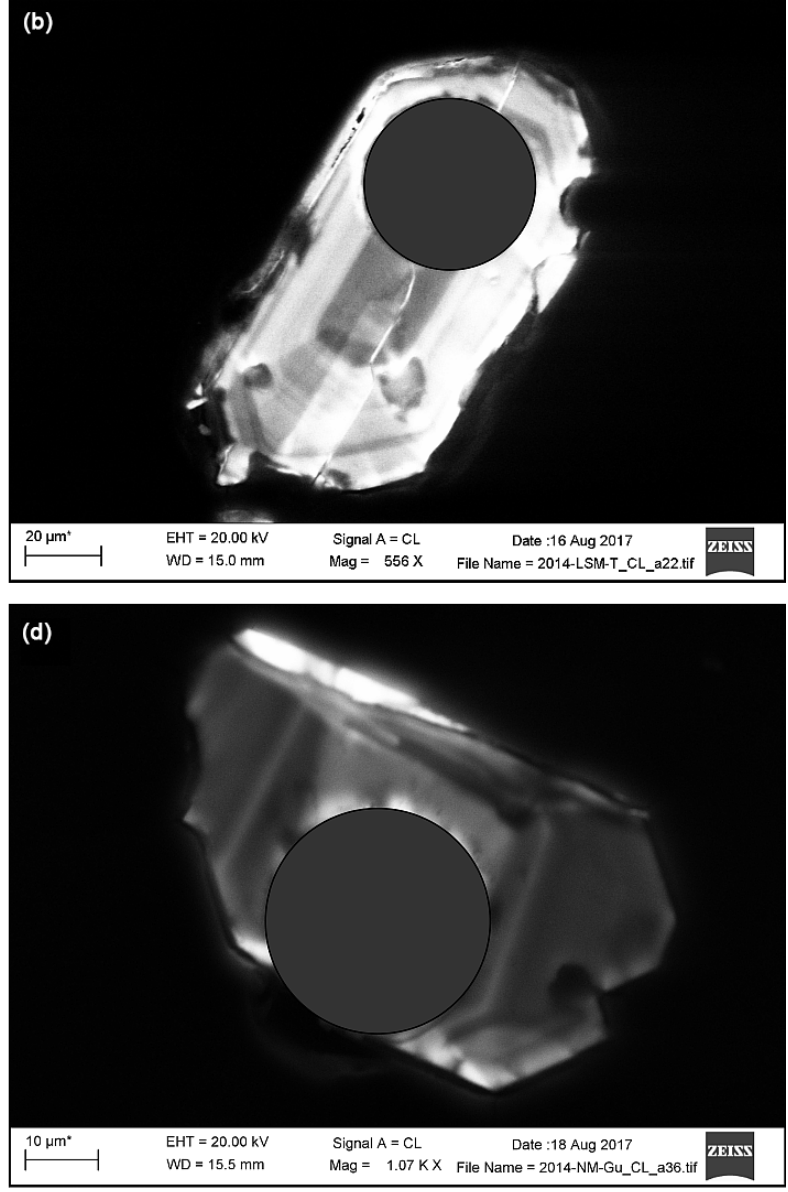

Figure 5. CL images of selected zircons which have been included in the age displays (including laser ablation mark). (a) La Sal Mountains tephra sampled in 2013: c13; (b) same but sampled in 2014: a22; (c) Tsankawi tephra: a38; (d) Guaje tephra: a36.

$1.341 \pm 0.059 \mathrm{Myr}$ (2014 sample, which had the smallest number of zircon ages within the overlapping cluster). The confidence intervals of the latter three samples do all overlap within errors. Therefore, we correlate these tephra-layer samples with the same, the Tsankawi eruption. The common age range within $2 \sigma$ of both samples is $1.31-1.40 \mathrm{Myr}$. We assume this is the most likely age array. Zoning of zircons indicates steady growth. If there is a core depicted in the CL images, the measuring spot may not be located at a core's edge (Fig. 5).

The ages derived via Ar-Ar dating are $1.264 \pm 0.010 \mathrm{Myr}$ (Phillips et al., 2007; recalculated by Zimmerer et al., 2016) and $1.223 \pm 0.018 \mathrm{Myr}$ (Izett and Obradovich, 1994); i.e., they are slightly younger than ours. Though being very close to each other, the U-Pb ages are slightly older. The common notion is that $\mathrm{Ar}-\mathrm{Ar}$ ages approximate the eruption ages and $\mathrm{U}-\mathrm{Pb}$ ages indicate the (earlier) time of crystal closure (Simon et al., 2008). However, this does not work for the Guaje tephra. Zimmerer et al. (2016) observed similar differences between ${ }^{40} \mathrm{Ar} /{ }^{39} \mathrm{Ar}$ and uranium-series (U/Th) ages for other tephras of the Jemez Mountains. They explain their findings with a complicated crystallization history of the magma, leading to disequilibrium between the uranium isotopes in the melt. Another explanation could be that the zircon crystal lattices of the Guaje tephra were not completely closed during eruption, as our sample was taken close to an underlying mafic lava bed which still could have been hot enough to achieve this effect. Or there still are problems with the $\mathrm{Ar}-\mathrm{Ar}$ dating of some Jemez tephras not yet understood.

Older zircons (cf. Supplement for raw data) are assumed to be inherited from rocks melted during magma rise, with those zircons being their most temperature-resistant components.

\section{Conclusions}

Our findings demonstrate that $\mathrm{U}-\mathrm{Pb}$ dating of zircons from Quaternary volcanic material may result in valuable age determination. $\mathrm{U}-\mathrm{Pb}$ dating of zircons seems to allow - at least combined with bulk geochemical analyses - confident distinction between the two tephras derived from the Jemez Mountains, which are too similar to be clearly kept apart by glass-shard chemistry alone. This approach avoids the 
complications accompanying the $\mathrm{Ar}-\mathrm{Ar}$ dating of Bandelier tephras (Phillips et al., 2007; Zimmerer et al., 2016).

We recommend considering $\mathrm{U}-\mathrm{Pb}$ dating as a possible approach to identifying rather young tephras or to distinguish such tephras, as in our study. However, before application, we recommend measuring total uranium contents in zircon minerals, which might indicate whether this dating method will be applicable.

In Quaternary research, dating of zircons as young as 1 Myr may well become a tool for better defining age models of sedimentary archives - such as loesses, cover beds, or paleosols - with interbedded or admixed tephra layers.

Data availability. All underlying data can be found in the Supplement.

Supplement. The supplement related to this article is available online at: https://doi.org/10.5194/egqsj-67-7-2018-supplement.

Competing interests. The authors declare that they have no conflict of interest.

Acknowledgements. We thank David B. Dethier, Williamstown, MA, USA, for sending samples from Jemez tephras and HansPeter Meyer, Heidelberg, Germany, for the electron-microprobe analyses. We also thank Rita Krause (Senckenberg Naturhistorische Sammlungen Dresden) for her invaluable support of our lab work. We are grateful to the San Ildefonso Indian Nation for allowing access to the Tsankawi sampling site. We thank two anonymous reviewers and Ludwig Zöller for their critical comments and helpful advice. Our work was supported by the German Research Foundation (DFG, KL 701/12-0).

\section{References}

Actlabs: Geochemistry/Assay Overview, available at: http://www.actlabs.com/Page.Aspx?Menu=64\&App= 210\&Cat $1=499 \& \mathrm{Tp}=2 \& \mathrm{Lk}=$ No, last access: 22 December 2014.

Bailey, R. A., Smith, R. L., and Ross, C. S.: Stratigraphic nomenclature of volcanic rocks in the Jemez Mountains, New Mexico, Geological Survey Bulletin, 1274-P, U.S. Government Printing Office, Washington, USA, 1969.

Dickinson, W. R. and Gehrels, G. E.: Use of U-Pb Ages of detrital zircons to infer maximum depositional ages of strata. A test against a Colorado Plateau Mesozoic database, Earth Planet. Sc. Lett., 288, 115-125, https://doi.org/10.1016/J.Eps1.2009.09.013, 2009.

Gehrels, G. E.: Detrital zircon U-Pb geochronology applied to tectonics, Annu. Rev. Earth Pl. Sc., 42, 127-149, https://doi.org/10.1146/Annurev-Earth-050212-124012, 2014.

Goff, F.: Valles Caldera. A geologic history, University of New Mexico Press, Albuquerque, USA, 2009.
Grahame, J. D. and Sisk, T. D.: La Sal Mountains, Utah, available at: https://web.archive.org/web/20060208054415/http: //www.cpluhna.nau.edu/index.htm (last access: 10 December 2014), 2002.

Henning, I.: Die La Sal Mountains, Utah. Ein Beitrag zur Geoökologie der Colorado-Plateau-Provinz und zur vergleichenden Hochgebirgsgeographie, Akademie der Wissenschaften und der Literatur, Mainz, Germany, 88 pp., 1975.

Ito, H., Nanayama, F., and Nakazato, H.: Zircon U$\mathrm{Pb}$ dating using LA-ICP-MS. Quaternary tephras in Boso Peninsula, Japan, Quat. Geochronol., 40, 12-22, https://doi.org/10.1016/j.quageo.2016.07.002, 2016.

Izett, G. A. and Obradovich, J. D.: ${ }^{40} \mathrm{Ar} /{ }^{39} \mathrm{Ar}$ age constraints for the Jaramillo Normal subchron and the Matuyama-Brunhes geomagnetic boundary, J. Geophys. Res., 99, 2925-2934, https://doi.org/10.1029/93JB03085, 1994.

Jones, R. L.: Barium in Illinois surface soils, Soil Sci. Soc. Am. J., 50, 1085-1087, 1986.

Kleber, A.: Heavy-mineral analysis as a tool in tephrochronology, with an example from the La Sal Mountains, Utah, USA, Geologos, 19, 87-94, https://doi.org/10.2478/logos-2013-0006, 2013.

Kues, B. S., Kelley, S. A., and Lueth, V. W. (Eds.): Geology of the Jemez region II. New Mexico Geological Society 58th Annual Field Conference, New Mexico Geological Society, 1922 September 2007, Socorro, NM, USA, 499 pp., 2007.

Lee, M. S. (Ed.): Mass Spectrometry Handbook, John Wiley and Sons, Inc, Hoboken, NJ, USA, 2012.

Lowe, D. J.: Tephrochronology and its application: a review, Quat. Geochronol., 6, 107-153, https://doi.org/10.1016/J.Quageo.2010.08.003, 2011.

Ludwig, R. K.: User manual for Isoplot. Ex Rev. 2.49, Berkeley Geochronology Center Special Publication, 1a, 1-58, https://doi.org/10.1016/S1471-3918(01)80062-9, 2001.

Phillips, E. H., Goff, F., Kyle, P. R., Mcintosh, W. C., Dunbar, N. W., and Gardner, J. N.: The ${ }^{40} \mathrm{Ar} /{ }^{39} \mathrm{Ar}$ age constraints on the duration of resurgence at the Valles Caldera, New Mexico, J. Geophys. Res., 112, 2925-2934, https://doi.org/10.1029/2006JB004511, 2007.

Richmond, G. M.: Quaternary stratigraphy of the La Sal Mountains, Geological Survey, Professional Paper 450-D, United States Government Printing Office, Washington, USA, 1962.

Ross, M. L.: Preliminary geologic map of the Warner Lake Quadrangle, Grand County, Utah, Utah Department of Natural Resources, Salt Lake City, USA, 18 pp., 2006.

Sakata, S., Hirakawa, S., Iwano, H., Danhara, T., Guillong, M., and Hirata, T.: A new approach for constraining the magnitude of initial disequilibrium in Quaternary zircons by coupled uranium and thorium decay series dating, Quat. Geochronol., 38, 1-12, https://doi.org/10.1016/j.quageo.2016.11.002, 2017.

Self, S., Heiken, G., Sykes, M. L., Wohletz, K., Fisher, R. V., and Dethier, D. P. (Eds.): Field excursions to the Jemez Mountains, New Mexico, New Mexico Bureau of Mines and Mineral Resources, Socorro, NM, USA, 1996.

Simon, J. I., Renne, P. R., and Mundil, R.: Implications of preeruptive magmatic histories of zircons for $\mathrm{U}-\mathrm{Pb}$ geochronology of silicic extrusions, Earth Planet. Sc. Lett., 266, 182-194, https://doi.org/10.1016/j.epsl.2007.11.014, 2008.

Slate, J. L., Sarna-Wojcicki, A. M., Wan, E., Dethier, D. P., Wahl, D. B., and Lavine, A.: A chronostratigraphic reference set of tephra 
layers from the Jemez Mountains volcanic source, New Mexico, in: Geology of the Jemez region II. New Mexico Geological Society 58th Annual Field Conference, New Mexico Geological Society, edited by: Kues, B. S., Kelley, S. A., and Lueth, V. W., 19-22 September 2007, Socorro, NM, USA, 239-247, 2007.

Spell, T. L. and Harrison, T. M.: ${ }^{40} \mathrm{Ar} /{ }^{39} \mathrm{Ar}$ geochronology of post-Valles Caldera rhyolites, Jemez volcanic field, New Mexico, J. Geophys. Res., 98, 8031-8051, https://doi.org/10.1029/92JB01786, 1993.

Westgate, J. A., Perkins, W. T., Fuge, R., Pearce, N., and Wintle, A. G.: Trace-element analysis of volcanic glass shards by laser ablation inductively coupled plasma mass spectrometry. Application to tephrochronological studies, Appl. Geochem., 9, 323335, https://doi.org/10.1016/0883-2927(94)90042-6, 1994.
Wilson, C. J. N., Charlier, B. L. A., Fagan, C. J., Spinks, K. D., Gravley, D. M., Simmons, S. F., and Browne, P. R. L.: U-Pb dating of zircon in hydrothermally altered rocks as a correlation tool: application to the Mangakino geothermal field, New Zealand, J. Volcanol. Geoth. Res., 176, 191-198, 2008.

Worsley, P.: Altersbestimmung, in: Geomorphologie. Ein Methodenhandbuch für Studium und Praxis, edited by: Goudie, A., Springer, Berlin, Germany, 447-558, 1998.

Zimmerer, M. J., Lafferty, J., and Coble, M. A.: The eruptive and magmatic history of the youngest pulse of volcanism at the Valles Caldera. Implications for successfully dating Late Quaternary eruptions, J. Volcanol. Geoth. Res., 310, 50-57, https://doi.org/10.1016/J.Jvolgeores.2015.11.021, 2016. 